\title{
Covid 19 Sürecinde Acil Uzaktan Öğretime Devam Eden Öğrenci Gruplarının Araştırma Topluluğuna Evrilmesi
}

\begin{tabular}{lccc}
\hline MAKALE TÜRÜ & Başvuru Tarihi & Kabul Tarihi & Yayım Tarihi \\
Araştırma Makalesi & 04.06 .2021 & 29.10 .2021 & 30.10 .2021 \\
\hline
\end{tabular}

\author{
Ebru Kuşcu (iD ${ }^{1}$ ve Adnan Ömerustaoğlu (iD ${ }^{2}$ \\ Biruni Üniversitesi
}

\begin{abstract}
Öz
Covid-19 salgını nedeniyle oldukça hazırlıksız başlayan acil uzaktan eğitimin etkililiği tüm dünyada sorgulanmaya başlamıştır. Bu çalışmada üniversite öğrencilerinin toplumsal, bilişsel ve öğretimsel buradalık algısının acil uzaktan eğitimdeki durumu araştırılmıştır. Araştırma nicel boyutta ilişkisel tarama modeli, nitel boyutta durum çalıșmasının olduğu karma araștırma yönteminde yürütülmüştür. Veriler araştırma topluluğu ölçeği, demografik bilgiler formu ve katılımcıların deneyimlerine ilişkin görüşlerinin yoklandığı açık uçlu sorulardan oluşan çevrimiçi bir araçla toplanmıştır. Çalışma grubu 153 öğrenciden oluşmaktadır. Grubun \%83.7'si kadın $(n=128)$ ve \%16.3'ü erkek $(n=25)$; yaş ortalaması ise 21 'dir. Cinsiyet ve öğrenme yönetim sistemlerinin öğretimsel, bilişsel ve sosyal buradalık üzerindeki etkisi Mann Withey-U ve bu üç öge arasındaki ilişki Spearman Brown katsayısı ile incelenmiştir. Öğrenci görüșleri betimsel analizle incelenmiş ve ölçek faktörlerini temele alan bir yaklaşımla kodlanarak doğrudan alıntılarla rapor edilmiştir. Sonuçta öğrencilerin öğretimsel buradalık puanlarının diğer buradalıklardan daha yüksek olduğu görülmüştür. Bilişsel buradalığın, öğretimsel buradalık ile pozitif yönlü ve yüksek bir ilişki gösterdiği, buna ek olarak sosyal buradalık ile orta düzeyli ve pozitif bir ilişkisinin olduğu anlaşılmıştır. Ayrıca bilişsel ve öğretimsel buradalık cinsiyete göre anlamlı bir biçimde farklılaşmıș; öğrenme yönetim sistemlerine göre üç buradalıkta da anlamlı bir fark oluşmamıştır. Öğrencilerin \%47'si yüz yüze, \%45.8'i karma buna karşın sadece \% 7.2'si tamamen çevrimiçi öğretimi tercih etmişlerdir.
\end{abstract} Anahtar sözcükler: Acil uzaktan öğretim, toplumsal, bilişsel ve öğretimsel buradalık, covid 19.

Etik kurul kararı: Biruni Üniversitesi 30.12.2020 tarih ve 2020/46-39 sayı ile Girişimsel Olmayan Klinik Araştırmalar Etik Kurulu'nca değerlendirilerek uygun bulunmuştur.

\footnotetext{
${ }^{1}$ Sorumlu Yazar: Doç. Dr., Eğitim Fakültesi, Eğitim Bilimleri Bölümü, Psikolojik Danışma ve Rehberlik Anabilim Dalı, E-posta: ebrukuscu894@gmail.com, https://orcid.org/0000-0002-1859-0286

${ }^{2}$ Prof.Dr., Eğitim Fakültesi, Eğitim Bilimleri Bölümü, Psikolojik Danışma ve Rehberlik Anabilim Dalı, Eposta: aomerustaoglu@biruni.edu.tr, https://orcid.org/0000-0002-9082-4235
} 
Covid-19 salgınının 2019'un sonlarına doğru tüm dünyada yayılmaya başlaması, insanların gündelik yaşantıları ile birlikte ekonomiyi, siyaseti, sağlık ve eğitim sistemlerini de derinden etkilemiştir. Bu nedenle tüm dünya ülkeleri başta sağlık sistemleri olmak üzere hukuk, ekonomi ve eğitim alanlarında çok ciddi önlemler almak zorunda kalmışlardır. Birleşmiş Milletler Eğitim, Bilim ve Kültür Örgütü’nün (UNESCO, 2020) istatistiklerine göre 188 ülkede, bir buçuk milyar çocuk ve genç Covid 19 nedeniyle yapılmayan ya da ara verilen eğitimle birlikte evlere kapanmıştır. Dünya Sağlık Örgütü küresel ölçekte öğrenci nüfusunun \%90'ından fazlasının bu durumdan etkilendiğini rapor etmiştir (World Health Organization-WHO, 2019). Bu bağlamda tüm dünyada eğitim kurumları geçici olarak kapatılıp sonrasında uzaktan eğitim süreçleri devreye konulmuştur (WHO, 2019). Ancak vurgulanması gereken önemli bir nokta, şu an tüm dünyada yürütülmeye çalışılan çevrimiçi eğitim süreçlerinin gerçek anlamda bir uzaktan eğitim olmayıp kriz dönemi nedeniyle uygulanan Acil Uzaktan Öğretim (Emergency Remote Teaching-ERT) olduğudur (Hodges, Moore, Lockee, Trust ve Bond, 2020; Zimmerman, 2020).

Covid-19 salgınıyla birlikte Türkiye'de de benzer kararlar alınmış ve 16 Mart 2020 tarihinden itibaren üniversiteler; 23 Mart 2020'den itibaren ilkokul, ortaokul ve liseler acil uzaktan eğitime geçiş yapmıştır (Milli Eğitim Bakanlığı-MEB, 2020; Yüksek Öğretim Kurulu-YÖK, 2020). Bu bağlamda yükseköğretim öğrencilerinin eğitimlerini uzaktan yürütmelerini sağlayan Adobe Connect (CATS) ve Mooddle gibi diğer lisanslı veya açı kaynak kodlu öğrenme yönetim sistemleri hem Türkiye hem de dünya ölçeğinde öğrenciler ve eğitimcileri bir araya getiren ortamlara dönüşmüşlerdir. Öğretimin çevrimiçi ortamlara taşınması öğrenmenin zaman ve mekan sınırı olmadan gerçekleşmesini sağlamak konusunda bir üstünlük sağlamaktadır. Ancak böylesi beklenmedik bir zamanda ve benzersiz bir hızla çevrimiçi eğitime geçmek hem öğrenciler ve ebeveynler hem de eğitimciler için oldukça şaşırtıcı ve stresli bir süreç olmuştur (Hodges ve diğ., 2020; Karadağ ve Yücel, 2020).

Bir anda tüm dünyanın eğitim süreçlerini çevrimiçi ortamlara taşıması, dijital ortamların ve uzaktan eğitim altyapısına sahip olmanın önemini bir kez daha göstermiştir. $\mathrm{Bu}$ durum gerek yükseköğretim gerek $\mathrm{K} 12$ düzeyindeki eğitim kurumlarını uzaktan eğitim süreçlerini daha etkin ve verimli kullanmanın yollarını aramaya zorlamaktadır. Ancak uzaktan öğretim ve öğrenmeyi içeren ve yıllardır araştırılan uzaktan eğitimin, öğrencilere etkili öğrenme deneyimleri sunmak için dikkatli bir şekilde tasarlanması gerektiği açıktır (Iglesias-Pradas, Hernández-García, Chaparro-Peláez ve Luis Prieto, 2021). Bu nedenle iyi planlanmış çevrimiçi öğrenme deneyimleri, bir bunalım veya felaket anlarında çevrimiçi sunulan acil uzaktan öğretim derslerinden anlamlı derecede farklıdır (Hodges ve diğ., 2020).

Şaşırtıcı sayıda çevrimiçi öğrenme sistemi ve etkinliği ile karşı karşıya kalan eğitimciler, öğretim süreçlerinin tasarımından çok çevrimiçi eğitim araçlarının teknik özelliklerine odaklanmak gibi bir yanılgıya kapılmışlardır (Rommie ve Duckworth, 2020). Bu durumda yalnızca dijital ortam ve araçların kullanımı ile üst düzey düşünme 
becerilerinin gelişmesi ve anlamlı etkileşimlerin oluşmasını beklemek çok gerçekçi olmayacaktır (Öztürk, Erdem ve Deryakulu, 2017).

Alanyazın incelendiğinde uzaktan öğrenme süreçlerindeki başarı ve memnuniyeti etkileyen pek çok değişkenin olduğu görülebilir. Örneğin pedagojik stratejiler, kolaylaştırıcı roller, hoşgeldiniz iletisi, öğrenci ve öğretmen profilinin sistemde yer alması, sesli iletişim araçlarının kullanılması, sınıftaki öğrenci sayısı, işbirliğine dayalı öğrenme etkinlikleri, bireysel ödevler, yazılı ödevler, öz değerlendirme araçları, kuramsal ders notları, okuma metinleri gibi tasarım ögeleri; program arayüzü, görevlerin doğası, öğrencilerle selamlaşma ve onları önemsediğini hissettirme, kişisel ve duygusal ifadeleri paylaşma, emojiler kullanma, farklı öğrencileri tartışmaya ve sürece katma, öğrencilerin e-postalarını anında yanıtlama, sık geri bildirim verme, tartışma forumlarına katkıda bulunma, mizahı kullanma gibi öğretmen davranışları ve grup etkileşim süreçleri uzaktan eğitim alanyazınında sıklıkla çalışılan değişkenlerdir. Bu bağlamda söz edilen değişkenler öğretim tasarım süreçlerinde belirleyici olmaktadır (Akyol ve Garrison, 2008; Alaulamie, 2014; Öztürk ve diğ., 2017; Richardson, Maeda, Lv ve Caskurlu, 2017).

Tamamen çevrimiçi veya karma (yüz yüze + çevrimiçi) öğrenme ortamlarındaki süreçleri anlayıp açıklamaya çalışan pek çok model bulunmaktadır. Gunawardena Lowe ve Anderson'in (1997) etkileşimsel analiz modeli ve Harasim (2006) tarafindan geliştirilen kavramsal değişim modeli bu modellerden bazılarıdır. Teknolojik ve kuramsal araştırma sonuçlarıyla geliştirilen bu modeller, derslerini anlamlı ve derin öğrenme yaşantılarıyla gerçekleştirmeyi hedefleyen öğretim üyeleri için yol gösterici olmaktadır. Ayrıca bireysel ve sosyal özelliklerin öğrenme üzerindeki etkisini anlamaya ve açıklamaya çalsşan eğitim bilimciler de bu modellerden yararlanmaktadır. Çevrimiçi öğrenme deneyimlerine yönelik en yaygın bilinen ve en iyi araştırılmış yaklaşımlardan biri araştırma topluluğu modelidir. Araştırma topluluğu kavramı, daha etkili bir çevrimiçi öğrenme ortamı oluşturmak için 2001 yılında Randy Garrison, Terry Anderson ve Walter Archer tarafindan geliştirilmiş ve ilgili model Şekil 1'de gösterilmiştir.

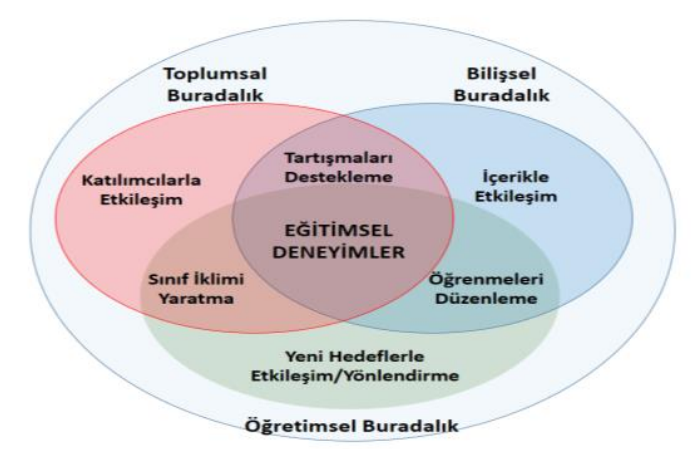

Şekil 1. Araştırma topluluğu modeli 
Bir araştırma topluluğu eğitimcisi, öğrencilerine onların bilmeleri gereken içeriklerin bir listesini sunmak için çevrimiçi etkinlikler planlamak yerine öğrencilerin içerikle anlamlı bağlantılar kurması için bir araya geldikleri ve birlikte çalıştıkları bir topluluk oluşturmayı amaçlar (Akyol ve Garrison, 2011). Çünkü araştırma topluluğuna göre bilgi öğretmenden öğrenciye basitçe aktarılan bir şey değildir. $\mathrm{Bu}$ bağlamda araştırma topluluğu modeli işbirliğine dayalı yapılandırmacı bir tasarımdır. Başka bir deyişle öğrenmenin, yeni bilgiler edinmenin ve anlamlandırmanın öğrencilerin etkin olarak birlikte çalışması ile gerçekleşebileceğini ileri süren bir modeldir (Rommie ve Duckworth, 2020). Bu nedenle araştırma topluluğu modeli, dijital araçlardansa çevrimiçi öğrenme süreçlerindeki eğitimin niteliğini önemser (Akyol ve Garrison, 2011). Şekil 1'de görüldüğü gibi öğretimsel (tasarım, düzenleme ve kolaylaştırma), bilişsel (tetikleyici olay, keşif, çözüm ve bütünleştirme) ve sosyal buradalık (açık iletişim, duygusal ifade ve grup uyumu) düzeyinin arttırılmasının önemini vurgulayan bu model, öğrenmeyi bu üç buradalık arasındaki ilişkinin sağladığını varsayar (Kozan ve Richardson, 2014).

Modelin önemli kavramlarından olan buradalık (presence) yapısının, çevrim içi öğrenme süreçlerindeki iç (özel) ve dış (paylaşılan) dünya arasındaki düşünce, duygu ve davranışların karşılıklı etkileşimiyle oluştuğu kabul edilmektedir (Garrison ve Arbaugh, 2007; akt., Öztürk ve diğ., 2017). Etkileşimli anlamsal süreçlerle gelişen buradalık yapısı, psikolojik ve toplumsal açıdan ele alınmalıdır (Noe, 2005, akt. Öztürk ve diğ., 2017). Öğrenme topluluğundaki katılımcıların bireysel özelliklerini yansıtarak diğer katılımcılarla olan ilişkilerini geliştirme ve kendini topluluğa ait hissetme algısı biçiminde tanımlanan sosyal buradalık (social presence), ödevleri tamamlamak için gruplar halinde çalıșmaktan çok daha fazlasıdır (Garrison, 2009). Öğrencilerin birbirleriyle çevrimiçi kullanıcı adları yerine gerçek kişiler olarak bağlantı kurma becerilerini de içeren sosyal buradalık, duygusal tutumların ve kişiler arası iletişim becerilerinin gelişimi için önemlidir (Rommie ve Duckworth, 2020).

Modelin ikinci ögesi olan bilişsel buradalık (cognitive presence), öğrencilerin birbirleriyle tartışıp derinlemesine düşünerek kendi anlamlarını oluşturabilmeleri hakkındaki algılarıdır. Başka bir deyişle bilişsel buradalık öğrencilerin kişisel düşünme ve eleştirel düşünmesini teşvik eden çevrim içi etkinlikler yoluyla bilgi toplama, becerileri geliştirme ve doğru tutumlar geliştirme çalışmalarını belirtir (Garrison, Anderson ve Archer, 2001).

Modelin üçüncü ögesi öğretimsel buradalık (teaching presence), öğretmenin yüz yüze ortamlardaki öğretim sürecinde olduğu gibi çevrimiçi süreçlerde de anlamlı ve eğitimsel değeri olan öğrenme çıktılarını gerçekleştirmek için bilişsel ve sosyal süreçleri planlaması, kolaylaştırması ve yönetmesidir. Başka bir söyleyişle öğretmenin bilişsel ve sosyal bileşenleri oluşturma ve sürdürme çabasıdır. Öğretimsel buradalığın yarattığı bu destek sayesinde öğrenciler bilgi toplamak, becerileri geliştirmek ve duyuşsal tutumlar geliştirmek için etkin olarak birlikte çalışırlar. Başka bir deyişle öğretimsel buradalık çevrim içi bileşenlerin geliştirilmesini ve 
düzenlenmesini, kursun kolaylaştırılmasını ve doğrudan öğretimini içeren bir yapı sergilemektedir.

Araştırma topluluğu modeli, yapılandırmacı yaklaşımda olduğu gibi bilgiye ulaşmanın ötesini amaçlamaktadır. Bu model, öğrencilerin etkin katılımı ve işbirliğiyle araştırmayı ve anlam yaratmayı sağlayacak öğrenen topluluklarının oluşmasını destekleyen bir sürece odaklanmaktadır (Akyol ve Garrison, 2011). Bu nedenle pek çok öğretim tasarımcısının çevrimiçi öğrenme ortamlarını planlayıp değerlendirirken kullandığı araştırma topluluğu modeli, acil uzaktan eğitim süreçlerinin tasarımlanmasında da etkili olabilir (Çakıroğlu ve Kılıç, 2020).

Bu bağlamda bir süre daha insanlığı etkileyebilecek Covid 19 salgını, çevrimiçi öğrenme süreçlerini yükseköğretimin önemli bir bileşeni durumuna getirmiştir. Ancak çevrimiçi öğretim süreçlerinin, yüz yüze olanlarından daha az etkili ve verimli olabileceği bilindiği için (Hachey, 2017) kriz durumlarında zorunlu olarak uzaktan yürütülen yükseköğretimin nasıl tasarlandığı daha da önem kazanmaktadır. $\mathrm{Bu}$ kapsamda araştırmanın amacı üniversitelerin uyguladığı acil uzaktan eğitimin etkililiğini araştırma topluluğu modeline göre incelemektir. Ayrıca geleneksel yüz yüze öğrenmede cinsiyet farkı çalışılmış olsa da (Wehrwein, Lujan ve DiCarlo, 2007), çevrimiçi öğrenme süreçlerini cinsiyete göre inceleyen az sayıda çalışma bulunmaktadır ve sonuçları genellikle çelişkilidir (Cuadrado-García, Ruiz-Molina ve Montoro-Pons, 2010). Örneğin Astleitner ve Steinberg (2005), web tabanlı öğrenmede cinsiyetin etkisine ilişkin 14 deneysel çalışmanın meta analizini gerçekleştirmiş ve cinsiyetin öğrenme çıktıları ile sosyal buradalık üzerindeki etkisinin anlamlı olmadığını öne sürmüştür. Ancak McSporran ve Young (2001) çevrim içi öğrenme ediminde cinsiyetin anlamlı bir fark oluşturduğunu rapor etmiştir. $\mathrm{Bu}$ bağlamda araştırmanın amacını gerçekleştirmek için aşağıdaki soruların yanıtı aranmıştır:

1. Acil uzaktan eğitim sürecindeki öğrencilerin, öğretimsel, bilişsel ve sosyal buradalık algıları ne düzeydedir?

2. Öğrencilerin öğretimsel, bilişsel ve sosyal buradalık algıları cinsiyete göre anlamlı olarak farklılaşmakta mıdır?

3. Öğrenim görülen üniversite (uzaktan eğitimin yürütüldüğü öğrenme yönetim sistemleri) öğretimsel, bilişsel ve sosyal buradalık algısını anlamlı olarak farklılaştırmakta mıdır?

4. Öğretimsel buradalık, bilişsel buradalık ve sosyal buradalık arasındaki ilişki anlamlı midır?

5. Öğrencilerin sadece yüz yüze, sadece çevrimiçi veya karma öğrenme modellerini tercih etme oranları nedir?

6. Acil uzaktan eğitim sürecindeki öğrenciler, öğretimsel, bilişsel ve sosyal buradalığa ilişkin deneyimlerini nasıl ifade etmektedirler? 


\section{Yöntem}

Bu bölümde çalışmada kullanılan araştırma modeli, araştırmanın veri kaynağ ve verilerin analiz aşamaları hakkında bilgi verilmiştir.

\section{Araştırma Modeli}

Çalışma, karma araştırma yaklaşımında desenlenmiş, nicel boyutunda ilişkisel tarama modeli, nitel boyutunda durum çalışması kullanılmış ve veriler betimsel analiz ile incelenmiştir. $\mathrm{Bu}$ bağlamda öğrencilere acil uzaktan eğitim sürecine ilişkin görüşlerin sorulduğu yarı yapılandırılmış sorular yöneltilmiş ve yanıtların betimsel analizi ile doğrudan alıntılama yapılarak nicel verilere destek kanıtlar sağlanmıştır. Araştırmanın nicel verileri ise araştırma topluluğu ölçeği ve kişisel bilgi formu ile çevrimiçi ortamda toplanmıştır.

Nitel araştırmalarda görüşme, gözlem ve yazılı materyallerin incelenmesi ile veri toplanabilir (Yıldırım ve Şimşek, 2016). Bu çalışmada öğrencilerin görüşleri Covid 19 salgını nedeniyle yüz yüze alınamadığı için ilgili sorular öğrencilere çevrimiçi ortamda ulaştırılmış ve konu hakkındaki görüşleri yazılı olarak alınmıştır.

\section{Çalışma Grubu}

Araştırmanın katılımcıları bu çalışma için belirlenen derse (öğretim teknolojileri) kayıtlı öğrencilerden oluşmuştur. İlgili ders, çalışmanın birinci yazarı tarafından 2019-2020 bahar döneminde iki ayrı vakıf üniversitesinde yürütülmüştür. Bu nedenle araştırma bulguları bu öğrenci grubuyla sınırlıdır. Çalışmaya toplam 153 öğrenci katılmıştır. Çalışma grubu \%32.4 $(n=48)$ ve \%68.6'lık $(n=105)$ dağılımla iki üniversitenin öğrencilerinden oluşmuştur. Grubun \%83.7'si kadın $(n=128)$, \%16.3'ü erkektir $(n=25)$. Ayrıca \%38.6'sı $(n=59)$ Psikolojik Danışmanlık ve Rehberlik (PDR), \%32'si ( $n=49)$ okul öncesi öğretmenliği ve \%24.4'ü $(n=45)$ özel eğitim öğretmenliği bölümüne devam etmektedir. Ayrıca her iki üniversitedeki öğrencilerin cinsiyet ve yaş dağılımlarının benzer olduğu, buna karşın kayıtlı oldukları lisans programlarına ilişkin dağılımlarının benzer olmadığı (çalışmaya katılan bir üniversitenin özel eğitim öğretmenliği bölümü bulunmamaktadır) saptanmıştır. Bu nedenle üniverisiteler arası karşılaştırmada Üniversite B olarak kodlanan üniversitenin özel eğitim öğretmenliğine devam eden öğrenciler, ilgili hipotez test edilirken analiz dişında tutulmuştur. Grubun yaş ortalaması 21'dir (18-35 yaş aralığında).

Çalışma süreci. Çalışmanın katılımcıları 2019-2020 bahar döneminin 5 . haftasına kadar yüz yüze eğitim almışlardır. Ancak Covid 19 salgını nedeniyle 6 . haftadan itibaren tüm yükseköğretim kurumlarının acil uzaktan eğitim sürecine geçmesiyle birlikte çalışma grubu da tamamen çevrimiçi eğitim sürecine geçmiştir. Dönemin dokuz haftalık bölümü çevrimiçi olarak iki üniversitenin iki ayrı öğrenme yönetim sisteminde (biri Moodle ve diğeri CATS) yürütülmüştür. Ders süreci tüm gruplarda aynı yaklaşım, aynı ders materyalleri ve aynı öğrenme görevleri ile yürütülmüştür. İlgili dersin içeriği, Yüksek Öğretim Kurulu'nun yaptığı ders tanımlarına uygun olarak belirlenmiştir. 
Çalışmanın yürütüldüğü ders, araştırma topluluğu ilkelerine uygun olarak tasarlanmış̧ır. Bu bağlamda her ders sayfasına hoşgeldiniz iletisi yazılıp duyurular aracında sabitlenmiştir. Her ders başlangıcında önce öğrencilerle selamlaşıp güncel durumları hakkında sohbet edilmiştir. Bu durum öğretmenin öğrencileri önemsediğini hissettirmesi açısından önemlidir (Anderson, Liam, Garrison ve Archer, 2001). Ayrıca ders sürecinde öğrencilere isimleri ile hitap edilmiştir (Aragon, 2003). Kişisel hikayeler ve deneyimlerin paylaşımına zaman ayırıp mizah ve duygusal sembollerin kullanılmasına özen gösterilmiştir. Böylece öğrencilerin kendilerini güvenli bir sınıf ikliminde hissetmeleri sağlanarak görüşlerini çekinmeden dile getirmeleri desteklenmiştir. Ayrıca öğrencilerin ders sürecinde eş zamanlı sohbet aracını kullanmaları ve öğretmene sorular sormaları özendirilerek dersin etkileşimli geçmesi sağlanmış ve öğrencilere sık sık geri bildirim verilmiştir. Bunlara ek olarak öğretmen eşzamanlı ders süresince kamerasını açık tutmuş ve öğrencileri derse daha etkin katmayı hedeflemiştir. Öte yandan dersin öğrenme amaçlarına uygun işbirliğine dayalı öğrenme görevleri planlanarak öğrencilerin kendi anlamlarını oluşturma çabaları desteklenmiş̧ir. Eşzamansız tartışma araçlarından olan forumlarda öğrencilerin tartışmasını sağlayacak görevler tasarıma eklenmiştir. Bu doğrultuda ders süreçlerindeki etkinlikler, kullanılan stratejiler ve değerlendirmeler modelin vurguladığı ve önerdiği bilişsel, sosyal ve öğretimsel buradalık ilkelerine göre geliştirilmiştir (Anderson ve diğ., 2001). Sınav haftalarında öğrencilere başarılar dileyen iletiler gönderilerek-biz- duygusunu hissettirecek bir iletişim sağlanmaya çalışılmıştır. Böylece sosyal buradalığın duyuşsal, etkileşimli ve bütünleş̧irici özelliklerinin ortama yansıtılması amaçlanmıştır (Anderson ve diğ., 2001). Öğrencilerin bulundukları öğrenme topluluğundan öğrenmesine ilişkin algısı olan bilişsel buradalığı desteklemek için öğrencilerin merakını uyandıran makale ve videolar paylaşılmıştır. Ders sürecinde bu videolar ve makalelere ilişkin tartışmalar başlatılarak öğrencilerin derse etkin katılımları sağlanmıştır. Modelin diğer bir ögesi olan öğretimsel buradalık algısını desteklemek amacıyla dönem başında ders izlencesi öğrencilerle paylaşılmıştır. Ayrıca her haftaya ilişkin öğrenme amaçları ve ders materyalleri bir hafta öncesinden ilgili öğretim yönetim sistemine yüklenerek öğrenciler, dersin amaçlarından haberdar edilmiştir (Anderson ve diğ., 2001).

\section{Veri Toplama Araçları}

Veriler araştırma topluluğu ölçeği, demografik bilgiler formu ve katılımcıların deneyimlerine ilişkin görüşlerinin yoklandığı açık uçlu sorulardan oluşan çevrimiçi bir araçla toplanmıştır. Ölçme aracı her iki üniversiteden araştırmanın yapıldığı dersi alan tüm öğrencilere dönem bittikten sonra uygulanmıştır.

Araştırma topluluğu (Community of inquiry) ölçeği. Öztürk (2012) tarafından Türkçeye uyarlanan Araştırma Topluluğu Ölçeği (ATÖ), Arbaugh ve meslektaşları tarafından 2008 yılında geliştirilmiştir. Uyarlanan ölçeğin üç faktörlü olduğu doğrulayıcı ve açımlayıcı faktör analizleri ile ortaya konmuştur. Ölçeğe ilişkin geçerlik analizi sonuçları şöyledir: DFA sonucunda uyum indeksleri $\left(\chi^{2} / \mathrm{sd}\right)=1.76$ $\mathrm{RMSEA}=.074$, standardize edilmiş $\mathrm{RMR}=.05, \mathrm{NNFI}=.82, \mathrm{CFI}=.83$ olarak 
bulunmuştur. ATÖ’nin alt faktörleri ve ölçek maddeleri arasındaki ilişkinin .30'un üstünde olduğu saptanmıştır.

Alt faktörlerin güvenirliği Cronbach Alfa iç tutarlık katsayısı ile hesaplanmıştır (Bilişsel buradalık .75, sosyal buradalık .88 ve öğretimsel buradalığın .92). 27 maddeden oluşan ölçeğin sosyal buradalık alt boyutunun örnek bir maddesi "Çevrim içi ortamlar yoluyla konuşurken kendimi çok rahat hissettim." biçimindeyken; öğretimsel buradalık alt boyutuna ait bir diğer maddesi, "Öğretmenin sınıfın dersle ilgili çalışmalara odaklanmasını sağlaması öğrenmeme yardımcı oldu.” bilişsel buradalık alt boyutuna ilişkin bir diğer maddesi ise "Çevrim içi tartışmalar, farklı görüşleri anlamama yardım ederek değerli bir katkı sağladı." biçimindedir. Ölçeğin bu çalışma grubu için güvenirlik incelemeleri Cronbach Alfa iç tutarlık katsayısı ile yapılmış ve bilişsel buradalık için .89 , sosyal buradalık için .85 ve öğretimsel buradalık için .80 olarak hesaplanmıştır.

\section{Verilerin Analizi}

Cinsiyet ve öğretim yönetim sisteminin bağımlı değişkenlerde (bilişsel, sosyal ve öğretimsel buradalık) oluşturduğu farkın anlamlı olup olmadığı Mann Withey-U testi ile bilişsel, sosyal ve öğretimsel buradalık arasındaki ilişki ise Spearman Brown korelasyon katsayısı ile analiz edilmiştir. Spearman Brown korelasyon katsayısı, dağılımı normal olmayan sürekli değişkenler arasındaki ilişkinin belirlenmesinde kullanılmaktadır (Köklü, Büyüköztürk ve Çokluk Bökeoğlu, 2006). Bu araştırmada da bağımlı değişkenlerin tüm gruplar için parametrik testlerde karşılanması gereken normallik varsayımını karşılamadığı saptanmıştır. Hesaplanan Kolmogrov-Simigrov ve Shapiro-Wilk değerinin anlamlılık puanının .05'ten küçük olduğu dolayısı ile veri setinin normal dağılmadığı görülmüştür (Tablo 1 ve Tablo 2; Büyüköztürk, 2002). Ayrıca normallik varsayımı bir kez de çarpıklık katsayısı (ÇK-Skewness) ve basıklık katsayısı (BK-Kurtosis) değerleri ile incelenmiş ve sonuçlar Tablo 3 'te belirtilmiştir. Büyüköztürk'e (2002) göre bu değerler \pm 1 aralığında yer aldıklarında veri setinin normallik varsayımını karşıladığı, aksi durumda dağılımın normallik varsayımını karşılamadığı söylenebilir (Tablo 3).

\section{Tablo 1}

Bă̆ımlı Değişkenlerin Üniversite Değişkenine Göre Kolmogrow-Simirnov Normallik Testi Bulgularl

\begin{tabular}{llrrr}
\hline & Üniversite-Öğretim Yönetim sistemi & N & D & p \\
\hline Öğretimsel & Üniversite A (CATS_Adobe connect) & 48 & .165 & .000 \\
\cline { 2 - 2 } & Üniversite B (Mooddle-big blue) & 105 & .148 & .000 \\
\hline Sosyal & Üniversite A (CATS_Adobe connect) & 48 & .126 & .008 \\
Buradalık & Üniversite B(Mooddle-big blue) & 105 & $.071 \quad .182$ \\
\hline Bilişsel & Üniversite A (CATS_Adobe connect) & 48 & .141 & .002 \\
Buradalık & Üniversite B(Mooddle-big blue) & 105 & .095 & .001 \\
\hline Toplam & Üniversite A (CATS_Adobe connect) & 48 & $.160 \quad .000$ \\
& Üniversite B (Mooddle-big blue) & 105 & .089 & .009 \\
\hline
\end{tabular}


Cinsiyet için normallik varsayımı değerlendirilirken Shapiro-Wilk (erkeklerin örneklem sayısı < 30 olduğu için) katsayısı hesaplanmış ve sonuçlar Tablo 1'de belirtilmiştir. Tablo 1 incelendiğinde sosyal buradalık dışındaki tüm değişkenlere ait veri setlerinin normal dağılımı karşılamadığı anlaşılmaktadır. Tablo 2'de ise normal dağılım istatistikleri yer almaktadır.

Tablo 2

Bağımlı Değişkenlerin Cinsiyete Göre Shapiro-Wilk Normallik Testi Bulguları

\begin{tabular}{llrrr}
\hline & Cinsiyet & $\boldsymbol{N}$ & $\boldsymbol{W}$ & $\mathbf{p}$ \\
\hline Öğretimsel Buradalık & Kadın & 128 & .881 & .000 \\
\cline { 2 - 5 } & Erkek & 25 & .951 & .260 \\
\hline Sosyal Buradalık & Kadın & 128 & .964 & .002 \\
\cline { 2 - 5 } & Erkek & 25 & .986 & .971 \\
\hline Bilişsel Buradalık & Kadın & 128 & .937 & .000 \\
\cline { 2 - 5 } & Erkek & 25 & .965 & .531 \\
\hline Toplam & Kadın & 128 & .881 & .000 \\
\cline { 2 - 5 } & Erkek & 25 & .951 & .260 \\
\hline
\end{tabular}

Öğretim yönetim sistemi için ise Kolmogrov-Simigrov testi (her örneklem > 30 olduğu için) kullanılmış ve sonuçlar Tablo 2' de gösterilmiştir. Tablo 2 incelendiğinde erkeklerden elde edilen verilerin normal dağıldığı ancak kadınlardan elde edilen verilerin normal dağılımı sağlamadığı görülmektedir. Bir sonraki Tablo 3 'te bağımlı değişkenlere ilişkin basıklık ve çarpıklık katsayıları belirtilmektedir.

Tablo 3

Bağımlı Değişkenlere İlişkin Basıklık ve Çarpıklık Bulguları

\begin{tabular}{lrrrr}
\hline & Öğretimsel buradalık & Sosyal buradalık & Bilişsel buradalık & Toplam puan \\
\hline $\mathrm{N}$ & 153 & 153 & 153 & 153 \\
\hline Çarp1klık & 1.053 & -.554 & -.858 & -.916 \\
\hline Basıklık & 1.012 & .057 & .513 & .977 \\
\hline
\end{tabular}

Tablo 3'te belirtilen çarpıklık ve basıklık katsayıları incelediğinde sadece öğretimsel buradalığın normal dağılmadığı $(C ̧ K=-1.053, \mathrm{BK}=1.009)$ buna karşın diğer değişkenlerin normal dağıldığı anlaşılmaktadır. Ancak Kolmogrov-Simigrov ve Shapiro-Wilk değerleri incelendiğinde verilerin çok değişkenli normal dağılım varsayımını karşılamadığı anlaşıldığından, tüm istatistik analizlerde non parametrik teknikler tercih edilmiştir.

Açık uçlu görüşme sorularından elde edilen veriler araştırma topluluğunun alt faktörleri ile koşut biçimde tümdengelimsel yaklaşımla kodlanarak doğrudan alıntılar biçiminde aktarılmıştır. Buna koşut olarak açık uçlu görüşme sorularına verilen yanıtlar temelde öğretimsel buradalık, sosyal buradalık ve bilişsel buradalık temaları 
altında ele alınırken öğrencilerin yanıtlarında eğitim-öğretimin sürdürülmesine ilişkin tercihleri de çevrimiçi, karma ve yüzyüze temalarında incelenmiştir. Acil uzaktan eğitim sürecine ilişkin öğrenci yanıtlarından doğrudan alıntılar yapılarak nicel verilere destek kanıtlar sağlanmıştır (Büyüköztürk, Kılıç Çakmak, Akgün, Karadeniz ve Demirel, 2012; Karasar, 2005; Tavşancıl ve Aslan, 2001). Görüşme sorularına verilen yanıtlar iki akademisyen tarafindan kodlanmıştır. Kodlayıcılardan biri bu araştırmanın ilk yazarı, diğeri ise nitel araştırmalarda deneyimli bir eğitim teknoloğudur. Kodlayıcılar öğrenci görüşlerini Garrison, Anderson ve ve Archer'in (2010) Araştırma Topluluğu Modeli'nin alt fakörleri olan bilişsel, sosyal ve öğretimsel buradalık yapılarını temele alarak incelemiştir. Miles ve Huberman'a (1994) göre kodlayıcılar arası güvenirlik, üzerinde uzlaşılan kod sayısının toplam uzlaşılan ve uzlaşılamayan kod sayısına bölünmesiyle elde edilebilir (Bu çalışma için aynı kodlanan mesaj sayısı 135, farklı kodlanan mesaj sayısı 18'dir). Kodlayıcılar arası güvenirliğin \%80'e yakın olması, hatta verilerin büyüklüğüne göre \%90 veya fazlası olması önerilmektedir (Miles ve Huberman, 1994; akt., Arastaman, Fidan ve Fidan, 2018). Bu araştırmada kodlayıcılar arası güvenirlik \%88 olarak hesaplanmıştır.

\section{Bulgular}

Bu bölümde sırasıyla araştırma sorularına ilişkin bulgulara yer verilmiştir.

\section{Öğrencilerin Öğretimsel, Bilişsel ve Sosyal Buradalık Algı Düzeylerine İlişkin Sonuçlar}

Tablo 4'te betimsel istatistikler yer almaktadır. Betimsel istatistiklerin yer aldığ Tablo 4 incelendiğinde öğretimsel buradalığın $\overline{\mathrm{x}}=52.88$, bilişsel buradalığın $\overline{\mathrm{x}}=$ 45.10 ve sosyal buradalığın $\overline{\mathrm{x}}=31.44$ olduğu anlaşılmaktadır.

Tablo 4

Sosyal, Bilişsel ve Öğretimsel Buradalı̆̆a İlişkin Betimsel Bulgular

\begin{tabular}{lrrr}
\hline & $\mathrm{N}$ & $\overline{\mathrm{x}}$ & $\mathrm{SS}$ \\
\hline Öğretimsel Buradalık & 153 & 52.88 & 10.66 \\
Bilişsel Buradalık & 153 & 45.10 & 10.41 \\
Sosyal Buradalık & 153 & 31.44 & 7.85 \\
\hline
\end{tabular}

Tablo 4 incelendiğinde öğrencilerin acil uzaktan eğitim süreçlerine ilişkin olarak en yüksek öğretimsel buradalığı, ikinci sırada bilişsel buradalığı, üçüncü sırada ise sosyal buradalığı algıladıkları söylenebilir. Bu bulgu öğrencilerin çevrimiçi öğrenme süreçlerinde öğretim süreçlerinin tasarımı ve yürütülmesinde öğretmenlerin etkinlik ve çabalarını yeterli algıladıkları ayrıca öğretmenlerin çevrimiçi öğrenme ortamlarındaki rollerini daha önemli buldukları biçiminde yorumlanabilir. Bilişsel buradalık algılarının ikinci yüksek puanı alması da çevrimiçi ortamda gerçekleşen öğrenme süreçlerinden memnun oldukları, buna karşın kendilerini sınıfa ait hissetmek ve gerçek bir birey olarak çevrimiçi ortama yansıtmak biçiminde tanımlanan sosyal buradalık faktöründe ise diğer iki buradalığa göre daha düşük düzeyli bir algılarının 
olduğu söylenebilir. Öğrenci görüşlerinden elde edilen nitel bulgular da nicel bulguları desteklemektedir. Örneğin K111,

Uzaktan iletişimin zor olması normaldir. Bazı hocalarımız gerçekten bu süreçte yanımızdayken ve ona yönelik yol izlerken bazen sert bir duvar ile de karşılaştık. Yine de dönemi sağ salim bitirmenin mutluluğunu yaşıyoruz yorgun bir şekilde. Önümüzdeki senelerde bizlerin mesleki hayatlarımızda böyle bir şeyle karşılaşırsak nasıl davranacağımız gerektiği hakkında tecrübe edinmiş olduk.

diyerek öğretimsel buradalığın ne denli önemli bulduğunu belirtmiştir. Öte yandan K38 "Aslında beni olumsuz etkileyecek tek yanı ders sürecinin verimli geçip geçmemesi konusundaki endişelerimdi. Yanılmışım, öyle bir durum söz konusu olmadı." diyerek bu ortamdan öğrenme ve anlam oluşturmayla ilgili bilişsel buradalık algısına atıfta bulunmuştur. Aynı şekilde K80 de

Kaçırılan ya da anlamadığım dersleri tekrar izleyebilme özelliğini sevdim. Yüz yüze eğitimde bir sonraki derste yeni bir konuya geçildiği için geçen haftaki konu üzerinde fazla durma imkanı olmuyor. Dolayısıyla kaçırılan bir dersin telafisi kolay olmuyor. Ama online derste böyle bir imkanın bulunması verimi artıran bir etken diye düşünüyorum.

biçiminde görüşlerini dile getirerek bilişsel buradalığa atıfta bulunmuştur. Ayrıca öğrenciler en çok zorlandıkları ve en düşük algıladıkları sosyal buradalığa ilişkin çok çarpıcı görüşler dile getirmişlerdir. Örneğin E146 "Platonik bir aşka tutulmuşum gibi hissediyorum. Arkadaşlarımı, sınıfımı, hocaları görüyorum ama bir türlü kavuşamıyorum.” diyerek iletişim ve etkileşimden yoksun kalmayı aşık olduğu insana ulaşamamakla özdeşleştirmiştir. Öte yandan K129 "Bölüm hocalarımı, arkadaşlarımı özledim. Çünkü bana üniversite okuduğumu ve eğitimin yaşamımda bir mutluluk nedeni olduğunu hatırlatıyordu. Onlarla bir arada olmayı özledim.” diyerek okulun sosyal ortamına duyduğu özlemi dile getirerek neden kendini sosyal olarak oraya ait hissedemediğini belirtmiştir.

\section{Demografik Özelliklere İlişkin Bulgular}

Çalışmada öğretimsel, sosyal ve bilişsel buradalığın cinsiyet ve öğretime devam edilen üniversiteye (uzaktan eğitimin yürütüldüğü öğrenim yönetim sistemlerine) göre istatistiksel olarak anlamlı bir farklılık gösterip göstermediği incelenmiştir.

Cinsiyete ilişkin bulgular. Cinsiyete göre öğretimsel, bilişsel ve sosyal buradalığın anlamlı olarak farklılaşıp farklılaşmadığı bağımsız gruplar Mann-WitheyU testi ile değerlendirilmiştir. Çünkü cinsiyete göre bağımlı değişkene ilişkin veriler normal dağılımı sağlamamıştır (Tablo 2). Sonuçlar Tablo 5 'te gösterilmiştir. Tablo 5 incelendiğinde sosyal buradalık dışındaki değişkenler için cinsiyetin anlamlı bir fark oluşturduğu görülmüştür. 
Tablo 5

Araştırma Topluluğu Ögelerinin (Sosyal, Bilişsel ve Öğretimsel Buradalık) Cinsiyete Göre Mann Withey-U Sonucu

\begin{tabular}{|c|c|c|c|c|c|c|}
\hline & Cinsiyet & $\mathrm{N}$ & $\begin{array}{r}\text { Sira } \\
\text { ortamalası }\end{array}$ & $\begin{array}{r}\text { Sira } \\
\text { toplamı }\end{array}$ & $\mathrm{U}$ & $\mathrm{p}$ \\
\hline \multirow{2}{*}{$\begin{array}{l}\text { Öğretimsel } \\
\text { buradalık }\end{array}$} & Kadın & 128 & 81.88 & $10,481.00$ & \multirow{2}{*}{975} & \multirow{2}{*}{.002} \\
\hline & Erkek & 25 & 52.00 & $1,300.00$ & & \\
\hline \multirow{2}{*}{$\begin{array}{l}\text { Bilişsel } \\
\text { buradalık }\end{array}$} & Kadın & 128 & 80.14 & $10,258.00$ & \multirow{2}{*}{1198} & \multirow{2}{*}{.042} \\
\hline & Erkek & 25 & 60.92 & $1,523.00$ & & \\
\hline \multirow{2}{*}{$\begin{array}{l}\text { Sosyal } \\
\text { buradalık }\end{array}$} & Kadın & 128 & 78.91 & $10,101.00$ & \multirow{2}{*}{1355} & \multirow{2}{*}{.404} \\
\hline & Erkek & 25 & 67.20 & $1,680.00$ & & \\
\hline \multirow{2}{*}{ Toplam puan } & Kadın & 128 & 80.59 & $10,316.00$ & \multirow{2}{*}{1140} & \multirow{2}{*}{.023} \\
\hline & Erkek & 25 & 58.60 & $1,465.00$ & & \\
\hline
\end{tabular}

Öğretimsel buradalık ve bilişsel buradalık puanları incelendiğinde, kadınların erkeklere göre daha yüksek puan aldıkları ve bu farkın istatistiksel olarak anlamlı olduğu görülmektedir (Tablo 5). Ayrıca ölçek toplam puanında da kadınların lehine bir fark olduğu anlaşılmaktadır. Bu bulgu kadınların öğretmenin ders sürecindeki çevrim içi bileşenlerin geliştirilmesi ve düzenlenmesi, kursun kolaylaştırılması ve doğrudan öğretimini sağlamadaki çabasını fark ettikleri ve öğretmenin bu süreçteki rolünü erkek öğrencilere göre daha önemli algıladıkları biçiminde yorumlanabilir. Başka bir deyişle kadınların acil uzaktan eğitim sürecini yönetmede öğretmenlerin rolünü daha çok önemsedikleri söylenebilir. Ayrıca kadınların bilişsel buradalığa ilişkin algılarının erkeklerden daha yüksek çıkması ise çevrimiçi ortamdan öğrenmeye ilişkin olarak acil uzaktan eğitime erkeklerden daha iyi uyum sağladıkları biçiminde yorumlanabilir. Buna ek olarak öğrencilerin ilk beş hafta yüz yüze eğitim almaları ve uzaktan eğitim sürecine geçmeden önce birbirlerini tanımaları, sosyal buradalık algılarının aynı düzeyde olmasını açıklayan önemli bir etken olarak da değerlendirilebilir. Öte yandan acil uzaktan eğitim sürecine geçmek zorunda kalan öğrencilerin öğretimsel ve bilişsel buradalık puanlarının sosyal buradalık puanından daha yüksek olduğu da görülmüştür (Tablo 4). Katılımcılara yöneltilen görüşme sorularından yapılan doğrudan alıntılar da bu bulguyu desteklemektedir. Çünkü nitel bulgularda kadınların acil uzaktan eğitim süreçlerinin olumlu yanlarını daha çok önceledikleri anlaşılmıştır. Örneğin K20 adlı bir kadın katılımcı bu görüşünü,

Dersi veren bazı hocalarım çevrimiçi öğrenmenin dezavantajlarını avantajlara çevirdi. $\mathrm{Bu}$ da uygulama kısmında bana fikir verdi. Örneğin bazı hocalarım öğrendiğimiz bilgileri internet ağlarından faydalanarak videolarla pekiştirdi. Ayrıca bazı arkadaşlarım ise çevrimiçi öğrenme ortamının rahatlığından faydalanarak kendilerini daha kolay ifade etme şansı buldu. $\mathrm{Bu}$ da yüz yüze öğrenme ortamına göre fikir alışverişinin ve düşünce paylaşımının daha fazla olmasını sağladı ve bizi motive etti.

biçiminde belirtmiştir. Öte yandan erkek katılımcılar da bu ortama ilişkin olumsuz algılarını dile getirmişlerdir. Örneğin E12 adlı bir erkek katılımcı bu görüşünü 
"Hocalar hep çoğunluğa göre gidiyorlar. Sınıfın yüzdesi üzerine hesap ediyorlar. Ama 'adalet' bu değil ve herkes kendi evinde olmayabilir. Ben bu süreçte İstanbul'dan çıkamadım. Kendi memleketime dönemedim. Sürekli ödevler verildi. Virüse yakalansaydım bu kadar stresli olmazdım.” biçiminde dile getirmiştir.

Öğrenim görülen üniversiteye (uzaktan eğitimin yürütüldüğü öğrenme yönetim sistemlerine) ilişkin bulgular. Öğretimsel, bilişsel ve sosyal buradalığın devam edilen üniversiteye yani üniversitelerin uzaktan eğitim süreçlerini yürüttüğü öğrenme yönetim sistemlerine göre anlamlı olarak değişip değişmediği nonparametik bir test olan Mann Withey-U testi ile incelenmiş ve bulgular Tablo 6'da gösterilmiştir.

Ancak iki farklı üniversiteden çalışmaya katılan öğrencilerin kayıtlı oldukları lisans programlarına ilişkin dağılımın iki üniversitede benzer olmadığı (Çalışmaya katılan bir üniversitenin özel eğitim öğretmenliği bölümü bulunmadığı) saptanmıştır. $\mathrm{Bu}$ nedenle üniversiteler arası karşılaştırmada, Üniversite B olarak kodlanan üniversitenin özel eğitim öğretmenliğine devam eden öğrencileri, ilgili hipotezin test edilmesi işleminde analiz dişında tutulmuştur. $\mathrm{Bu}$ nedenle analiz sadece her iki üniversitenin okul öncesi öğretmenliği ve PDR bölümündeki öğrencilerden elde edilen verilerle gerçekleştirilmiştir.

Tablo 6

Sosyal, Bilişsel ve Öğretimsel Buradalı̆̆ın Katılımcıların Öğrenim Gördüğ̈̈u Üniversiteye (CATS Adobe Connect ve Mooddle-Big Blue) Göre Mann Withey-U Testi Sописи

\begin{tabular}{|c|c|c|c|c|c|c|}
\hline & Üniversite & $\mathbf{N}$ & $\begin{array}{c}\text { Sira } \\
\text { ortamalası }\end{array}$ & $\begin{array}{c}\text { Sira } \\
\text { toplamı }\end{array}$ & $\mathbf{U}$ & $\mathbf{p}$ \\
\hline \multirow{2}{*}{$\begin{array}{l}\text { Öğretimsel } \\
\text { buradalık }\end{array}$} & $\begin{array}{l}\text { Üniversite A } \\
\text { (CATS_Adobe } \\
\text { connect) }\end{array}$ & 48 & 54.71 & 2626.00 & \multirow[t]{2}{*}{1430.0} & \multirow[t]{2}{*}{.951} \\
\hline & $\begin{array}{l}\text { Üniversite B } \\
\text { (Mooddle-big blue) }\end{array}$ & 60 & 54.33 & 3260.00 & & \\
\hline \multirow{2}{*}{$\begin{array}{l}\text { Bilişsel } \\
\text { buradalık }\end{array}$} & $\begin{array}{l}\text { Üniversite A } \\
\text { (CATS_Adobe } \\
\text { connect) }\end{array}$ & 48 & 53.80 & 2582.50 & \multirow[t]{2}{*}{1406.5} & \multirow[t]{2}{*}{.836} \\
\hline & $\begin{array}{l}\text { Üniversite B } \\
\text { (Mooddle-big blue) }\end{array}$ & 60 & 55.06 & 3303.50 & & \\
\hline \multirow{2}{*}{$\begin{array}{l}\text { Sosyal } \\
\text { buradalık }\end{array}$} & $\begin{array}{l}\text { Üniversite A } \\
\text { (CATS_Adobe } \\
\text { connect) }\end{array}$ & 48 & 56.68 & 2720.50 & \multirow[t]{2}{*}{1335.5} & \multirow[t]{2}{*}{.518} \\
\hline & $\begin{array}{l}\text { Üniversite B } \\
\text { (Mooddle-big blue) }\end{array}$ & 60 & 52.76 & 3165.50 & & \\
\hline \multirow{2}{*}{$\begin{array}{l}\text { Toplam } \\
\text { puan }\end{array}$} & $\begin{array}{l}\text { Üniversite A } \\
\text { (CATS_Adobe } \\
\text { connect) }\end{array}$ & 48 & 55.76 & 2676.50 & \multirow[t]{2}{*}{1379.5} & \multirow[t]{2}{*}{.708} \\
\hline & $\begin{array}{l}\text { Üniversite B } \\
\text { (Mooddle-big blue) }\end{array}$ & 60 & 53.49 & 3209.50 & & \\
\hline
\end{tabular}


Tablo 6 incelendiğinde farklı üniversitelerde olmak dolayısıyla farklı öğrenme yönetim sistemleri aracılılığıyla uzaktan eğitim almanın öğrencilerin öğretimsel, bilişsel ve sosyal buradalık algısını istatistiksel olarak anlamlı bir biçimde farklılaştırmadığı anlaşılmaktadır. Bu bulgu çevrimiçi eğitimin niteliğinin, öğretim yönetim sistemleri ya da kullanılan teknolojiden daha çok, ders sürecinin tasarlanması ve öğretmen yeterlikleri gibi değişkenlerden etkilendiği biçiminde yorumlanabilir.

\section{Sosyal, Bilişsel ve Öğretimsel Buradalık Arasındaki İlişkiye İlişkin Korelasyon Analizi Bulguları}

Öğretimsel, sosyal ve bilişsel buradalık arasındaki ilişki, veriler parametrik istatistikler için gerekli olan normallik varsayımını karşılamadığı için Spearman Brown korelasyon katsayısı ile incelenmiştir. Sonuçlar Tablo 7'de yer almaktadır. Tablo 7 incelendiğinde öğretimsel ve bilişsel buradalık arasında yüksek ve anlamlı bir ilişki; sosyal ve bilişsel buradalık arasında ise orta düzeyli ve anlamlı bir ilişki olduğu anlaşılmaktadır.

Tablo 7

Öğretimsel, Sosyal ve Bilişsel Buradalık Arasındaki İlişkiye Ait Spearman Brown Korelasyon Katsayıs Sonucu

\begin{tabular}{|c|c|c|c|c|}
\hline & $\begin{array}{r}\text { Öğretimsel } \\
\text { Buradalık } \\
\end{array}$ & $\begin{array}{r}\text { Sosyal } \\
\text { Buradalık } \\
\end{array}$ & $\begin{array}{r}\text { Bilişsel } \\
\text { Buradalık } \\
\end{array}$ & $\begin{array}{c}\text { Araştırma Topluluğu } \\
\text { Ölçeği Toplam Puan }\end{array}$ \\
\hline Öğretimsel buradalık & 1.00 & & & \\
\hline Sosyal buradalık & $.498 *$ & 1.00 & & \\
\hline Bilişsel buradalık & $.698 *$ & $.619 *$ & 1.00 & \\
\hline $\begin{array}{l}\text { Araştırma topluluğu } \\
\text { ölçeği toplam puan }\end{array}$ & $.851 *$ & $.787 *$ & $.911 *$ & 1.00 \\
\hline
\end{tabular}

Bilişsel ve öğretimsel buradalık arasındaki ilişkinin gücü $r=.698(p<.001)$; bilişsel ve toplumsak buradalık arasında ilişkinin gücü $r=.619(p<.001)$; sosyal ve öğretimsel buradalık arasındaki ilişkinin gücü ise $r=.498(p<.001)$ olarak ölçülmüştür. Bununla birlikte araştırma topluluğu ölçeği toplam puanı ile alt faktörleri arasındaki ilişkinin gücü değerlendirildiğinde ise bilişsel buradalık-toplam puan $r=$ $.911(p<.001)$; ögretimsel buradalık- toplam puan $r=.851(p<.001)$ ve sosyal buradalık-toplam puan $r=.787$ ( $p<.001$ ) olarak ölçülmüştür (Tablo 7).

Tablo 7'deki ilişkilere ait değerler sosyal bilimlerde de yaygın olarak tercih edilen Cohen'in (1992) $r$ katsayasına ilişkin değerlere göre değerlendirilmiştir. Buna göre $r$ katsayısının .19 ve altı çok düşük, .20 - .39 düşük, .40 - .69 orta, .70 - .89 yüksek ve .90 - 1 çok yüksek ilişki olarak değerlendirilmektedir.

$\mathrm{Bu}$ bağlamda alt faktörler arasındaki $\mathrm{r}$ puanları incelendiğinde öğretimsel ve bilişsel buradalık arasında yüksek ve pozitif yönlü bir ilişkinin $(r=.698)$ olduğu anlaşılmaktadır. $\mathrm{Bu}$ bulgu, öğrencilerin çevrimiçi öğrenme topluluklarındaki 
öğretmenin çevrim içi öğrenme süreçlerinin tasarlanması, kolaylaştırılması ve topluluk hissinin desteklemesi sürecine olan etkisini belirten ğretimsel buradalık ile etkileşim ve tartışmalardan öğrenme ve anlam oluşturmaya ilişkin öğrenci algısı olan bilişsel buradalık arasındaki ilişkiyi önceledikleri biçiminde yorumlanabilir. $\mathrm{Bu}$ bulgu, acil uzaktan eğitim sürecindeki öğrencilerin, öğretmenin ders materyallerini paylaşması, ders etkinliklerini yönetmesi, öğrencilere geri bildirim vermesi ve çevrimiçi ders sürecindeki öğrenci-öğretmen etkileşimini yönlendirmesi gibi öğretimsel süreçlerde öğretmeni daha önemli ve etkili algılamış oldukları anlamına gelebilir. Öte yandan sosyal buradalık ile bilişsel buradalık arasında ise orta düzeyli ve pozitif yönlü bir ilişkinin $(r=.619)$ saptanması ise öğrencilerin kendilerini diğer katılımcılarla birlikte ve aynı ortamda hissetme duygularının, öğrenme algıları ile önemli bir ilişkisinin olduğunu göstermek açısından dikkate değerdir. Çünkü çevrim içi ortamdaki öğretmen ve öğrenciler arasındaki iki yönlü etkileşim, öğrencilerin kendini bir gruba ait ve orada hissetmesine olanak sağlamaktadır. Bu durum, katılımcıların sanal ortamda kendilerini gerçek bir birey olarak hissetmelerini ve bulunduğu sanal sınıfa güven duyarak sınıf içi tartışmalara rahatça katılmalarını sağladığını göstermektedir. Ayrıca bu sanal sınıfta bireysel anlamlarını yapılandıran öğrenciler için bir topluluk hissinin oluşması açısından da önemlidir.

\section{Tercih Edilen Öğretim Modeline İlişkin Bulgular}

Öğrencilerin seçme şansları olması durumunda yüz yüze, tamamen çevrimiçi ve karma öğrenme modellerinden hangisini seçecekleri sorulmuştur. Öğrenci yanıtları Tablo 8'de görülmektedir. Bu tabloya göre öğrencilerin birinci sırada (\%47) yüz yüze eğitimi, ikinci sırada karma öğretim modelini (\%45.8), son sırada ise tamamen çevrimiçi $(\% 7.2)$ eğitimi tercih ettikleri anlaşılmaktadır.

Tablo 8

Tercih Edilen Öğretim Modeline İlişkin Oranlar

\begin{tabular}{lrr}
\hline Öğretim modeli & Sıklık & Oran \\
\hline Karma öğrenme (çevrimiçi+yüz yüze) & 70 & 45.8 \\
\hline Çevrimiçi & 11 & 7.2 \\
\hline Yüz yüze & 72 & 47.1 \\
\hline Toplam & 153 & 100.0 \\
\hline
\end{tabular}

Bu bulgu öğrencilerin yüz yüze eğitimi diğer iki modele göre birinci sırada tercih ettiklerini göstermiştir. Öte yandan bu bulgu öğrencilerin karma eğitime karş1 olumsuz bir tutumlarının olmadığı biçiminde de yorumlanabilir. Örneğin karma öğrenmeyi tercih edeceğini belirten E138 bu görüşünü,

Bence online eğitim süreci karma olarak devam etmeli gerçekten bedenen dinlenmiş ve zaman bakımından çok büyük tasarruf fakat tek bi sorun var öğretmenler uzaktan eğitimi sadece bi slayt okumaktan itibaren sanması olayı sıkıcı hale getiriyor nasıl yüz yüze eğitimde slayt ve kendi yorumlarını katıyorsa 
sorular soruyorsa bize online eğitimde bunu yapmalı süreç ilerledikçe bu daha iyi olacaktır diye düşünüyorum.

biçiminde belirtirken sadece yüz yüze eğitimi tercih eden katılımcılar yüz yüze eğitimin sosyalleşme ve iletişim yönünü vurgulamışlardır. K65 bu konudaki görüşünü, "Arkadaş ortamımı, öğretmenle direk teması özledim. Şöyle arkadaşlarım dersten kopsam da motive ediyorlar. Ayrıca öğretmenle de bir konuyu daha rahat konuşarak kendimi daha iyi ifade edebiliyorum." biçiminde dile getirmiştir. Öte yandan sadece çevrimiçi eğitimi tercih eden E23, "Dersleri istediğim yerden ve istediğim zamanda kayıttan tekrar izleyebiliyorum ayrıca okula gitme derdi de kalmadı." biçiminde belirtmiştir. Benzer olarak K5 de "Daha rahat ve özgür olabilmek. Hem düşünce hem de görünüş olarak. Çünkü bazıları için fikirlerini söylemek zor olabilir, online eğitimde bu daha kolay aynı şekilde görünüşüne de önem vermek zorunda olmuyorsun.” diyerek online eğitimin üstünlüklerini (avantajlarını) vurgulamıştır.

\section{Tartışma, Sonuç ve Öneriler}

Araştırma sonucunda acil uzaktan eğitim sürecine geçmek zorunda kalan öğrencilerin öğretimsel ve bilişsel buradalık algılarının sosyal buradalık puanlarından daha yüksek olduğu ve öğrencilerin orta düzeyde sosyal buradalık algıladıkları görülmüştür. Bu durum Covid 19 salgını sırasında yapılan diğer çalışmalarla benzerlik göstermektedir (Erickson ve Wattiaux, 2021; Whittle, Tiwari, Yan ve Williams, 2020). Örneğin Erickson ve Wattiaux (2021), Covid 19 salgını sürecinde acil uzaktan eğitime geçiş yapan bir grup üniversite öğretim elemanı ve öğrencileriyle yürüttükleri bir çalışmada, öğrencilerin öğretimsel ve bilişsel buradalık algılarının yüksek, buna karşın sosyal buradalıklarının orta düzeyli olduğunu ortaya koymuşlardır. Araştırmacılar öğrencilerin öğretimsel buradalı̆̆ diğer buradalıklara göre daha yüksek algılamalarının doğal bir sonuç olduğunu iddia etmişlerdir. Bu durumu, acilen geçilmek zorunda kalınan uzaktan eğitimdeki öğretmenin daha etkin olması ve öğretmen merkezli öğretim tasarımlarını tercih etmesi ile açıklamışlardır. Yani öğretim üyelerinin ders konusu, ders hedefleri, görev tarihleri ve öğretim yöntemlerini açıkça belirtmesi, öğretimsel buradalığın daha yüksek algılanmasını sağlamıştır biçiminde belirtmiştir (Erickson ve Wattiaux, 2021). Öte yandan sosyal buradalık algılarının çok farklılaşması ise öğrencilerin kendilerini gruba ait hissedemedikleri veya dersin diğer katılımcılarıyla olumlu bir ilişki kuramadıklarını düşünmelerinden kaynaklanmış olabileceğini göstermektedir. Kimi araştırmacılar bu durumu çevrimiçi öğrenme ortamının doğası gereği yüz yüze iletişimin bazı özelliklerini (jest, mimik, ses tonu, beden dili, vurgu ve giyim vb.) barındırmamasına bağlamış ve öğrencilerin bu iletişim kayıpları nedeniyle kendini yalnız ve yalıtılmış hissettiklerini iddia etmişlerdir (Morgan ve Tam, 1999; Wang, 2008). Benzer olarak bu çalışmada da öğrencilerin sosyal buradalık algısı, öğretimsel ve bilişsel buradalığa göre daha düşük çıkmıştır. Öğrencilerin öğrenmeyle, öğretmenle ve diğer öğrencilerle olan ilişkilerinde ani bir kayıp yaşaması, öğrencilerin sosyal buradalık algısını olumsuz yönde etkilemiştir (Whittle ve diğ., 2020). Zaten öğrencilerin aşık oldukları kişiye erişememek, uzak ilişki yaşamak, sevgilisinin askerden dönmesini beklemek gibi 
ifadeleri ile sosyal ilişkilerin eğitim sürecindeki eksikliğini hissetmeleri sonucunu desteklemektedir. Öte yandan bilişsel ve öğretimsel buradalık algısına ilişsin puanların alanyazındaki diğer bulgularla benzer olduğu da gözlenmiştir (Akyol ve Garrison, 2008; Öztürk ve diğ. 2017). Bu nedenle acil uzaktan eğitim süreçlerindeki çevrim içi öğrenme topluluklarında oluşması beklenen bilişsel ve öğretimsel buradalık algısının beklenen düzeyde geliştiği söylenebilir. Bu bağlamda sosyal buradalık algısının öğrenci memnuniyetinin sağlanmasında önemli bir değişken olduğunu açıkça ortaya koyan Erickson ve Wattiaux (2021), sosyal buradalıkla birlikte öğretimsel ve bilişsel buradalık yapılarının güçlendirildiği acil uzaktan eğitim süreçlerine gereksinim olduğunu iddia etmiştir.

Araştırmanın bir diğer sonucu kadınların öğretimsel buradalık ve bilişsel buradalık algısının daha yüksek olması, buna karşın sosyal buradalık algısının cinsiyete göre değişmemesidir. Bu bulgu kadınların acil uzaktan eğitim sürecindeki öğretmenin gerçekleştirdiği öğretim süreçlerini, öğrenmeye olan katk1 ve yönlendirmelerini daha önemli ve olumlu algıladıklarını düşündürmüştür. Ayrıca bilişsel buradalık puanları erkeklere göre daha yüksek çıkan kadınların acil uzaktan eğitim süreçlerindeki öğrenme deneyimlerini erkeklere göre daha olumlu algıladıklarını göstermiştir. Buna karşın sosyal buradalık algısının cinsiyete göre anlamlı olarak farklılaşmaması da dikkat çekmektedir. Bu durum öğrencilerin acil uzak eğitim sürecine geçmeden önceki beş haftalık süreçte yüz yüze eğitimde birbirleriyle sosyalleşmiş ve birbirlerini daha önceden tanıyor olmaları ile açıklanabilir. Ancak vurgulanması gereken bir diğer önemli sonuç ise araştırma topluluğu ölçeğinden alınan toplam puanın cinsiyete göre karşılaştırıldığında kadınların lehine istatistiksel olarak anlamlı bir fark çıkmış olmasıdır. Sonuç olarak kadınlar erkeklere göre kendilerini çevrimiçi ortama daha çok ait hissederek acilen oluşturulan bu öğrenme topluluğuna daha kolay uyum sağlamışlardır. Katılımcılara yöneltilen görüş̧e sorularından yapılan doğrudan alıntılar da bu bulguyu desteklemektedir. Çünkü nitel bulgularda kadınların acil uzaktan eğitim süreçlerinin olumlu yanlarını daha çok önceledikleri anlaşılmıştır. Öte yandan erkek katılımcılar ise acil uzaktan eğitim süreçlerine ilişkin olumsuz algılarını dile getirmişlerdir. Alanyazın incelendiğinde ise cinsiyetin araştırma topluluğunun üç boyutu olan öğretimsel, bilişsel ve sosyal buradalık üzerinde anlamlı bir etkisinin olup olmadığına ilişkin bir görüş birliği olmadığı anlaşılmaktadır (Gibson, Ice, Mitchell, ve Kupczynski, 2012; Khodabandelou, Jalil, Ali ve Daud, 2014; Rovai ve Baker, 2005).

Farklı üniversitelerde olmak dolayısıyla farklı öğrenme yönetim sistemleri aracılllığıyla uzaktan eğitim almak, öğrencilerin öğretimsel, bilişsel ve sosyal buradalık algılarında anlamlı bir fark oluşturmamıştır. Bu bulgu çevrimiçi eğitimin niteliğinin, öğretim yönetim sistemleri ya da kullanılan teknolojidense ders sürecinin tasarlanması ve öğretmen yeterliklerinden daha çok etkilendiği anlamına gelebilir. Araştırma topluluğu modeli, işbirliği içinde düşünme ve öğrenmeye dayalı eğitim deneyimini yeniden şekillendiren ve öğrencilerin edilgen olduğu bir dersten uzaklaşmayı hedefleyen kurumsal bir yaklaşımdır (Cleveland-Innes, Garrison ve Vaugan, 2018). Elbette teknolojinin evrimi ve çevrimiçi öğrenmede kullanımı, 
öğrenenler için etkili öğrenme firsatları sunmaya başlamıştır. Bu bağlamda araştırma topluluğu modeline göre öğrenme etkinliklerinin seçimi, tasarımı ve kolaylaştırılması, öğretim süreçlerinin temel bileşenleridir ve üç buradalığın ortaya çıkması için de kritik öneme sahiptir (Morueta, Maraver López, Hernando Gómez ve Harris, 2016). Ancak sıklıkla belirtildiği gibi, sahip olduğunuz şey değil, onunla ne yaptığınız önemlidir. Örneğin bilişsel buradalığın geliştirilmesinin anahtarı, etkili soruların geliştirilmesidir (firsatlar ortaya çıktıkça hem planlı hem de kendiliğinden). Araştırmalar soruların gerçek olarak algılandığından ve en azından öğrencilerin olası kişisel deneyimlerine dayandığından emin olmanın, bilişsel buradalığın gelişimini tetiklediğini iddia etmektedirler. McLoughlin ve Mynard (2009), herhangi bir teknoloji ile kullanılması gereken etkili uygulamaları incelediği bir çalışmasında teknolojinin sahip olduğu özelliklerin tek başına etkili olamayacağını iddia etmiştir. $\mathrm{Bu}$ bağlamda öğretmen öğrenme hedefleriyle tutarlı, uygun görevler vermez ve yönlendirmelerini dikkatlice belirtmezse ya da açık yönergeler ve katılımcılar için uygun örnekler sağlamazsa ve öğrencilere zamanında geri bildirim vermezse hiçbir teknolojik altyapının üst düzey düşünmeyi geliştiremeyeceğini öne sürmüştür.

Çevrim içi ortamlarda üst düzey öğrenme ve düşünmeyi oluşturmak için bilişsel buradalığın önemi alanyazında geniş çapta rapor edilmiştir (Garrison ve diğ., 2001; Rourke ve Kanuka 2009). Garrison ve diğ., (2001), bilişsel buradalı̆ğ öğrencilerin eleştirel bir araştırma topluluğunda sürekli düşünme ve tartışma yoluyla anlamı inşa etme ve onaylama derecesi olarak tanımlamaktadır. Bu nedenle bir çevrimiçi öğrenme topluluğunda bilişsel buradalığı destekleyen bir sosyal ve öğretimsel buradalık yapısının oluşturulması önemlidir. Bu bağlamda bu araştırmada sosyal ve öğretimsel buradalığın, bilişsel buradalıkla anlamlı bir ilişkisinin olup olmadığı incelenmiş ve araştırma sonucunda öğretimsel buradalığın, bilişsel buradalıkla sosyal buradalığa göre daha yüksek düzeyde ve güçlü bir ilişki gösterdiği anlaşılmıştır. Ancak alanyazın incelendiğinde, bu çalışma sonucunun aksine öğretimsel değil sosyal buradalığın bilişsel buradalıkla daha yüksek ve anlamlı bir ilişkisinin olduğu görülmektedir (Gutiérrez-Santiuste, Rodríguez-Sabiote ve Gallego-Arrufat, 2015; Öztürk ve diğ., 2017). Bilişsel ve sosyal buradalık arasındaki ilişkinin daha önemli olduğunu savunan bu çalışmalara göre yükseköğretimde hedeflenen bilişsel yetenekler (çıkarımlar yapmak, bağlantıları gözlemlemek, onaylamak ve düzenlemek), işbirliği içinde bütünleştirildiğinde daha iyi sonuçlar üretmektedir ve bu durum sosyal buradalıkla desteklenip sürdürülmektedir (Gunawardena, 1995). Zaten bir öğrenme topluluğu içindeki bilişsel süreçlerin amacı da yansıtma ve tartışma yoluyla anlamın çözümlenmesi, oluşturulması ve onaylanmasını özendirmektir. Ancak bir yandan da acil uzaktan eğitim sürecinde sosyal buradalık yerine öğretimsel buradalığın daha önemli algılanması doğaldır (Erickson ve Wattiaux, 2021). Çünkü gerçek bir uzaktan eğitim ya da karma öğrenme olarak tasarlanmasına zaman kalmadan deneyimlenen bu acil uzaktan eğitim sürecinde öğretmenler, daha merkezde yer almış ve ders içeriklerini bir biçimde öğrencilere aktarmaya odaklanmışlardır. Böylece acil uzaktan eğitim sürecindeki öğrenciler, öğretmenin ders materyallerini paylaşması, ders etkinliklerini yönetmesi, öğrencilere geri bildirim vermesi ve çevrimiçi ders 
sürecindeki öğrenci-öğretmen etkileşimini yönlendirmesi gibi öğretimsel süreçlerde öğretmeni daha önemli ve etkili algılamış olabilirler. Öte yandan sosyal buradalığın da bilişsel buradalıkla anlamlı ve orta düzeyde bir ilişki göstermesi, öğrencilerin kendilerini diğer katılımcılarla birlikte ve aynı ortamda hissetme duygularının, öğrenme algısı üzerinde ne kadar etkili olduğunu göstermek açısından dikkate değerdir. Çünkü çevrim içi ortamdaki öğretmen ve öğrenciler arasındaki iki yönlü etkileşim, öğrencilerin kendini bir gruba ait ve orada hissetmesine olanak sağlamaktadır. Bu durum katılımcıların sanal ortamda kendilerini gerçek bir birey olarak hissetmelerini ve bulunduğu sanal sınıfa güven duyarak sınıf içi tartışmalara rahatça katılmalarını sağlamaktadır. Bu bağlamda araştırma topluluğu modelinin, acil uzaktan eğitim süreçlerinin değerlendirilmesi için geçerli bir model olduğunu ve gelecek çalışmalarda sosyal buradalığın hangi değişkenlerden etkilenebileceği ve ne tür tasarım ögeleri ile sürecin desteklenebileceğine ilişkin çalışmaların yapılması önemli görülmektedir (Erickson ve Wattiaux, 2021).

Araştırmanın ortaya koyduğu bir diğer sonuç, öğrencilerin \%47'sinin yüz yüze öğretimi, \%45.8'inin karma öğretimi, buna karşın sadece \%7.2'sinin tamamen çevrimiçi öğretimi tercih ettiklerini saptamak olmuştur. Bu sonuç öğrencilerin yüz yüze eğitime yakın bir oranda karma öğrenmeyi tercih ettiklerini göstermiştir. Bir başka deyişle 21. yüzyıl gençliğinin eğitim süreçleri ile teknolojinin bütünleşmesi ve teknolojinin eğitimde etkin kullanımı konusunda olumlu bir tutuma sahip olduklarını göstermiştir. Ayrıca araştırmanın nitel boyutunda elde edilen öğrenci görüşlerinde bu bulguyu destekleyen ifadelere de rastlanmıştır.

Sonuç olarak araştırma topluluğu modelinin acil uzaktan eğitim süreçlerinin geliştirilmesi ve değerlendirilmesinde rehberlik edebilecek kuramsal bir model olduğu anlaşılmaktadır. Çalışmanın en çarpıcı sonucu, sosyal buradalık algısının bilişsel ve öğretimsel buradalık algılarından anlamlı olarak düşük çıkması olmuştur. Buna karşın araştırma topluluğu modelinin temel ögelerinden olan bilişsel buradalığın öğretimsel buradalık ile pozitif yönlü ve yüksek düzeyli bir ilişki göstermesi ayrıca sosyal buradalık ile orta düzeyli ve pozitif bir ilişkisinin olması da modelin geçerliğini tekrar doğrulamak adına önemli bir sonuçtur. Alanyazında özellikle vurgulanan bu ilişki, sosyal buradalığın, gerek üst düzey bilişsel öğrenme hedeflerinin gerçekleşmesi için gerek öğrenci memnuniyetinin sağlanması için ne denli önemli olduğu ile de tutarlıdır (Gutiérrez-Santiuste ve diğ., 2015). Bu nedenle çevrimiçi öğrenme topluluklarında sosyal buradalığı güçlendirecek tasarım ögelerinin neler olabileceği hakkında eğitimcilere hizmet içi eğitimlerin sağlanması önerilebilir. Çünkü sanal öğrenme topluluklarındaki sosyal buradalık yeterince güçlendirilebilirse üyeler arasındaki iletişim, üst düzey eleştirel düşünme ve işbirliğine yönlendirebilir. Ayrıca kişisel iletişimin öğrenme hedeflerine yönlendirilmesinde etkili olunabilir.

\section{Etik Kurul Kararı}

Bu araştırma Biruni Üniversitesi 30.12.2020 tarih ve 2020/46-39 sayı ile Girişimsel Olmayan Klinik Araştırmalar Etik Kurulu'nca değerlendirilerek yapılması uygun bulunmuştur. Çalışmaya katılımda gönüllülük esas alınmıştır. 


\section{Kaynakça}

Akyol, Z., and Garrison, D. R. (2008). The development of a community of inquiry over time in an online course: Understanding the progression and integration of social, cognitive and teaching presence. Journal of Asynchronous Learning Networks, 12(3-4), 3-22. Retrieved from https://files.eric.ed.gov/fulltext/EJ837483.pdf

Akyol, Z., and Garrison, D. R. (2011). Assessing metacognition in an online community of inquiry. The Internet and Higher Education, 14(3), 183-190. doi: 10.1016/j.iheduc.2011.01.005

Alaulamie, L. A. (2014). Teaching presence, social presence, and cognitive presence as predictors of students' satisfaction in an çevrimiçi program at a Saudi University (Doctoral dissertation). Retrieved from https://www.proquest.com/docview/1646485924?pqorigsite $=$ gscholar $\&$ fromopenview $=$ truehttps://etd.ohiolink.edu/

Anderson, T., Liam, R., Garrison, D. R., and Archer, W. (2001). Assessing teaching presence in a computer conferencing context. Journal of Asynchronous Learning Networks, 5(2), 1-17.doi: 10.24059/olj.v5i2.1875

Aragon, S. R. (2003). Creating social presence in online environments. New Directions for Adult and Continuing Education, 2003(100), 57-68. doi: 10.1002/ace. 119

Arastaman, G., Fidan, İ. Ö. ve Fidan, T. (2018). Nitel araştırmada geçerlik ve güvenirlik: Kuramsal bir inceleme. Yüzüncü Yıl Üniversitesi Eğitim Fakültesi Dergisi, 15(1), 37-75. doi: 10.23891/efdyyu.2018.61

Astleitner, H., and Steinberg, R. (2005). Are there gender differences in web-based learning? An integrated model and related effect sizes. AACE Review (formerly AACE Journal), 13(1), 47-63. Retrieved from https://www.semanticscholar.org/paper/Are-there-gender-differences-in-webbased-learning-AstleitnerSteinberg/41390b3bcff0bd083ea6c300f411d6f55255fe01

Büyüköztürk, Ş. (2002). Faktör analizi: Temel kavramlar ve ölçek geliştirmede kullanımı. Kuram ve Uygulamada Eğitim Yönetimi, (32), 470-483. https://dergipark.org.tr/tr/download/article-file/108451 adresinden erişilmiştir.

Büyüköztürk, Ş., Kılıç Çakmak, E., Akgün, Ö. E., Karadeniz, Ş. ve Demirel, F. (2012). Bilimsel araştırma yöntemleri (13.Bask1), Ankara: Pegem Akademi Yayınları.

Cleveland-Innes, M., Garrison, D. R., and Vaughan, N. (2018). The community of inquiry theoretical framework: Implications for distance education and beyond. In M. G. Moore, and W. C. Diehl (Eds), Handbook of distance education (pp. 67-78). New York: Routledge. 
Cohen, J. (1992). A power primer. Psychological Bulletin, 112(1), 155-159. doi: 10.1037/0033-2909.112.1.155

Cuadrado-García, M., Ruiz-Molina, M. E., and Montoro-Pons, J. D. (2010). Are there gender differences in e-learning use and assessment? Evidence from an Interuniversity online project in europe. Procedia-Social and Behavioral Sciences, 2(2), 367-371. doi: 10.1016/j.sbspro.2010.03.027

Çakıroğlu, N., and Kılıç, S. (2020). Understanding community in synchronous online learning: Do perceptions match behaviours? Open Learning: The Journal of Open, Distance and e-Learning, 35(2), 105-121. doi: 10.1080/02680513.2018.1500888

Erickson, M., and Wattiaux, M. A. (2021). Practices and perceptions at the COVID19 transition in undergraduate animal science courses. Natural Sciences Education, 50(1). doi: 10.1002/nse2.20039

Garrison, D. R. (2009). Implications of online and blended learning for the conceptual development and practice of distance education. Journal of Distance Education, 23(2), 93-104. Retrieved from http://www.ijede.ca/index.php/jde/article/view/471

Garrison, D. R., Anderson, T., and Archer, W. (2001). Critical thinking, cognitive presence, and computer conferencing in distance education. American Journal ofDistance Education, 15(1), 7-23. doi: 10.1080/08923640109527071

Garrison, D. R., Anderson, T., and Archer, W. (2010). The first decade of the community of inquiry framework: A retrospective. Internet and Higher Education, 13(1), 5-9. Retrieved from https://www.learntechlib.org/p/108352/

Gibson, A. M., Ice, P., Mitchell, R., and Kupczynski, L. (2012). An inquiry into relationships between demographic factors and teaching, social, and cognitive presence. Internet Learning, 1(1), 7-17. doi: 10.18278/il.1.1.2

Gunawardena, C. N. (1995). Social presence theory and implications for interaction and collaborative learning in computer conferences. International Journal of Educational Telecommunications, 1(2), 147-166. Retrieved from https://www.learntechlib.org/primary/p/15156/

Gunawardena, C. N., Lowe, C. A., and Anderson, T. (1997). Analysis of a global online debate and the development of an interaction analysis model for examining social construction of knowledge in computer conferencing. Journal of Educational Computing Research, 17(4), 397-431. doi: 10.2190/7mqv-x9ujc7q3-nrag

Gutiérrez-Santiuste, E., Rodríguez-Sabiote, C., and Gallego-Arrufat, M. J. (2015). Cognitive presence through social and teaching presence in communities of inquiry: A correlational-predictive study. Australasian Journal of Educational Technology, 31(3). doi: 10.14742/ajet.1666

Hachey, V. K. (2017). Nontraditional student participation in asynchronous online discussions (Doctoral dissertation). University of Minnesota. Retrieved from 
https://www.proquest.com/docview/1936663074?pq-

origsite $=$ gscholar $\&$ fromopenview $=$ true

Harasim, L. (2006). Assessing online collaborative learning: A theory, methodology, and toolset. In B. Khan, (Ed.) Flexible learning in an information society (pp. 282-293). Hershey, PA: Idea Group Publishing.

Hodges, C., Moore, S., Lockee, B., Trust, T., and Bond, A. (2020). The difference between emergency remote teaching and online learning. Retrieved from https://er.educause.edu/articles/2020/3/the-difference-between-emergencyremote-teaching-and-online-learning

Iglesias-Pradas, S., Hernández-García, Á., Chaparro-Peláez, J., and Luis Prieto, J. L. (2021). Emergency remote teaching and students' academic performance in higher education during the COVID-19 pandemic: A case study. Computers in Human Behavior, 119, Article 106713. doi: 10.1016/j.chb.2021.106713

Karadağ, E. ve Yücel, C. (2020). Yeni tip koronavirüs pandemisi döneminde üniversitelerde uzaktan eğitim: Lisans öğrencileri kapsamında bir değerlendirme çalışması. Yükseköğretim Dergisi, 10(2), 181-192. doi: 10.2399/yod.20.730688

Karasar, N. (2005). Bilimsel araştırma yöntemi. Ankara: Nobel.

Khodabandelou, R., Jalil, H. A., Ali, W. Z. W., and Daud, S. B. M. (2014). Moderation effect of gender on relationship between community of inquiry and perceived learning in blended learning environments. Contemporary Educational Technology, 5(3), 257-271. doi: 10.30935/cedtech/6128

Kozan, K., and Richardson, J. C. (2014). Interrelationships between and among social, teaching, and cognitive presence. The Internet and Higher Education, 21, 68-73. doi: 10.1016/j.iheduc.2013.10.007

Köklü, N., Büyüköztürk, Ş. ve Çokluk Bökeoğlu, Ö. (2006). Sosyal bilimler için istatistik (2. Baskı). Ankara: Pegem A yayınc1lı.

McLoughlin, D., and Mynard, J. (2009). An analysis of higher order thinking in online discussions. Innovations in Education and Teaching International, 46(2), 147160. doi: 10.1080/14703290902843778

McSporran, M., and Young, S. (2001) Does gender matter in online learning?, Research in Learning Technology, 9(2). doi: 10.1080/0968776010090202

Milli Eğitim Bakanlığı. (2020). Bakan Selçuk, 23 Mart'ta başlayacak uzaktan ĕgitime ilişkin detaylarl anlattl. https:/www.meb.gov.tr/bakan-selcuk-23-marttabaslayacak-uzaktan-egitime-iliskin-detaylari-anlatti/haber/20554/tr adresinden erişilmiştir.

Morgan, C. K., and Tam, M. (1999). Unravelling the complexities of distance education student attrition. Distance Education, 20(1), 96-108. doi: $10.1080 / 0158791990200108$ 
Morueta, T.R., Maraver López, P., Hernando Gómez, N., and Harris, V. W. (2016). Exploring social and cognitive presences in communities of inquiry to perform higher cognitive tasks. The Internet and Higher Education, 31, 122-131. doi: 10.1016/j.iheduc.2016.07.004

Öztürk, E. (2012). An adaptation of the community of inquiry index: The study of validity and reliability. Ilkogretim Online, 11(2), 408-222. Retrieved from https://core.ac.uk/reader/230030190

Öztürk, E., Erdem, M. ve Deryakulu, D. (2017). Toplumsal buradalık ve öğretimsel buradalığın bilişsel buradalığı yordama gücü. Kastamonu Eğitim Dergisi, 25(4), 1319-1336 https://dergipark.org.tr/en/pub/kefdergi/issue/30766/332463 adresinden erişilmiştir.

Richardson, J. C., Maeda, Y., Lv, J., and Caskurlu, S. (2017). Social presence in relation to students' satisfaction and learning in the online environment: A metaanalysis. Computers in Human Behavior, 71, 402-417. doi: 10.1016/j.chb.2017.02.001

Rommie, L., and Duckworth, L.P. (2020). Duckworth on education: Community of inquiry. Retrieved from https://www.emsworld.com/article/1224658/duckwortheducation-community-inquiry

Rourke, L., and Kanuka, H. (2009). Learning in communities of inquiry: A review of the literature. International Journal of E-Learning \& Distance Education, 23(1), 19-48. Retrieved from https://files.eric.ed.gov/fulltext/EJ836030.pdf

Rovai, A., and Baker, J. (2005). Gender differences in online learning: Sense of community, perceived learning, and interpersonal interactions. The Quarterly Review of Distance Education, 6(1), 31-44. https://www.proquest.com/openview/91c2490769e5513a142b05a64cf8c33c/1? pq-origsite $=$ gscholar $\& \mathrm{cbl}=29705$

Tavşancıl, E. ve Aslan, E. (2001). İçerik analizi ve uygulama örnekleri. İstanbul: Epsilon.

United Nations Educational, Scientific and Cultural Organization. (2020). Education: From disruption to recovery. Retrieved from https://en.unesco.org/Covid19/educationresponse

Wang, S. K. (2008). The effects of a synchronous communication tool (yahoo messenger) on online learners' sense of community and their multimedia authoring skills. Journal of Interactive Online Learning, 7(1), 59-74. Retrieved from http://www.ncolr.org/jiol/issues/pdf/7.1.4.pdf

Wehrwein, E. A., Lujan, H. L., and DiCarlo, S. E. (2007). Gender differences in learning style preferences among undergraduate physiology students. Advances in Physiology Education, 31(2), 153-157. doi: 10.1152/advan.00060.2006

Whittle, C., Tiwari, S., Yan, S., and Williams, J. (2020). Emergency remote teaching environment: A conceptual framework for responsive online teaching in crises. 
Information and Learning Sciences, 121(5/6), 311-319. doi: 10.1108/ils-042020-0099

World Health Organization. (2019). Coronavirus disease (COVID-19). Retrieved from https://www.who.int/emergencies/diseases/novel-coronavirus2019/strategies-plans-and-operations

Yıldırım, A. ve Şimşek, H. (2016). Sosyal bilimlerde nitel araştırma yöntemleri. Ankara: Seçkin.

Yükseköğretim Kurulu. (2020). YÖK'ten koronavirüs (Covid-19) hakkında yükseköğretim kurumlarında alınacak tedbirlere ilişkin öneriler. https://www.yok.gov.tr/sayfalar/haberler/2020/coronavirus-hastaligina-iliskinuniversitelerde-alinacak-tedbirler.aspx adresinden erişilmiştir.

Zimmerman, J. (2020). Coronavirus and the great online-learning experiment. Chronicle of Higher Education, 66(25), 37-47. Retrieved from https://www.chronicle.com/article/coronavirus-and-the-great-online-learningexperiment/ 


\title{
Evolution of Student Groups Continuing Emergency Remote Teaching into Research Community in the Covid 19 Process
}

\begin{tabular}{cccc}
\hline $\begin{array}{l}\text { ARTICLE TYPE } \\
\text { Research Article }\end{array}$ & $\begin{array}{c}\text { Received Date } \\
06.04 .2021\end{array}$ & $\begin{array}{c}\text { Accepted Date } \\
10.29 .2021\end{array}$ & $\begin{array}{c}\text { Published Date } \\
10.30 .2021\end{array}$ \\
\hline \multirow{2}{*}{ Ebru Kuşcu } & \multicolumn{2}{c}{${ }^{1}$ and Adnan Ömerustaoğlu } & \multirow{2}{*}{${ }^{2}$} \\
Biruni University
\end{tabular}

\begin{abstract}
The effectiveness of emergency remote teaching (ERT), which started quite unprepared due to the Covid-19 epidemic, has begun to be questioned all over the world. In this study, social, cognitive, and teaching presence in this process was investigated. The research was carried out in a mixed research method with a quantitative relational survey model and a qualitative descriptive analysis. Data were collected using an online tool consisting of a research community scale, demographic information form, and open-ended questions about their experiences. $83.7 \%$ of the study group were female $(n=128)$ and $16.3 \%$ were male $(n=25)$; The average age is 21 . The impact of gender and learning management systems (LMS) on teaching cognitive and social presence was examined by Mann Withey- $U$ and the relationship among them is examined with the Spearman-Brown coefficient. Student opinions were analyzed with descriptive analysis and coded with an approach based on scale factors and reported with direct quotations. As a result, it was seen that the students perceived the teaching presence higher than the other presences. Cognitive presence has a positive and high relationship with teaching presence; it has a moderate and positive relationship with social presence. In addition cognitive and teaching presence differed significantly by gender. According to the LMS, there was no significant difference in all three elements. $47 \%$ of the students preferred face-to-face, $45.8 \%$ chose blended learning, whereas only $7.2 \%$ opted for completely online teaching.
\end{abstract}

Keywords: Social, cognitive and teaching presence, emergency remote teaching, covid 19.

Ethics Committee Approval: It was approved by the Biruni University Non-Interventional Clinical Research Ethics Committee with the evaluation dated 30.12.2020 and numbered 2020/46-39.

${ }^{1}$ Corresponding Author: Assoc. Prof., Faculty of Education, Science of Education, E-mail: ebrukuscu894@gmail.com, https://orcid.org/0000-0002-1859-0286

${ }^{2}$ Prof. Dr. Faculty of Education, Science of Education, E-mail: aomerustaoglu@biruni.edu.tr, https://orcid.org/0000-0002-9082-4235 


\section{Purpose and Significance}

The Covid-19 epidemic, which affected the whole world towards the end of 2019 , forced all countries to take serious measures in education. According to the statistics of United Nations Educational, Scientific and Cultural Organization (UNESCO, 2020), 1.5 billion children and young people are confined to their homes in 188 countries. World Health Organization (WHO, 2019) reported that more than $90 \%$ of the student population globally is affected by this condition. However, it should be emphasized that the online education processes being conducted at the moment are not real distance education but Emergency Remote Teaching (ERT), which must be employed in times of crisis (Zimmerman, 2020). Transferring face to face teaching to online environments certainly provides an advantage in making teaching and learning processes flexible enough to take place anywhere and anytime. However, moving to online education at such an unexpected time and with an unprecedented speed has been a surprising and stressful process for both students, parents, teachers, and administrators (Karadağ and Yücel, 2020).

This confusion in the field of education has shown that distance education must be designed very carefully. One of the most widely known and best-researched approaches to online learning experiences is the community of inquiry model (CoI).

A research community educator aims to create a community where students work together to make meaningful connections with the content, rather than presenting a list of content in their courses (Akyol and Garrison, 2011). Because according to the CoI, knowledge is not something that is simply passed on from teacher to student. This model, which emphasizes the importance of increasing the level of teaching presence, cognitive presence and social presence argues that learning is provided by the relationship between these three presences (Kozan and Richardson, 2014).

The research CoI model focuses on an educational experience that facilitates the formation of learner communities that enable students to explore, create meaning, and validate meaning through active participation and collaboration (Akyol and Garrsison, 2011). Therefore, many instructional designers use it when planning and evaluating online learning environments which can also be effective in designing ERT (Çakıroğlu and Kılıç, 2020). In this context, the Covid 19 epidemic, which may affect humanity for a while, has made online learning processes an important component of higher education. However, since it is known that online teaching processes can be less effective and efficient than face-to-face ones (Hachey, 2017), it becomes even more important how compulsory distance education is designed in crises. In this context, this research aims to examine the effectiveness of ERT applied by universities according to the CoI model. To this end, answers to the following questions were sought:

1. What is the level of teaching, cognitive and social presence perceptions of students in the ERT? 
2. Do students' perceptions of teaching, cognitive and social presence differ significantly according to gender in the ERT?

3. Does the university (LMS) significantly differentiate the perception of teaching, cognitive and social presence?

4. Is the relationship between teaching presence, cognitive presence and social presence statistically significant?

5. What is the rate of students preferring only face-to-face, only online, or blended learning models?

6. How do students in the ERT express their experiences of teaching, cognitive, social and presence?

\section{Method}

The study was designed in a mixed research approach. While the relational survey model was used in the quantitative dimension, case study and to analyse the data descriptive analysis was used in the qualitative dimension. In this context, the students were given semi-structured interview questions in which their opinions on the ERT were asked. The descriptive analysis of the answers and direct quotations from them were provided as evidence for the quantitative data. The quantitative data of the study were collected online with the research community scale and personal information form.

The course was conducted by the lead author of the study in two different foundation universities. Therefore, the research findings are limited to this student group. A total of 153 students participated in the study. $83.7 \%$ of the group were female $(n=128), 16.3 \%$ were male $(n=25)$. The average age of the group is 21 (range 18-35).

The course in which the study was conducted was designed following the principles of the research community. A welcome message is written on each course page and fixed in the announcements tool. At the beginning of the lessons, the students were greeted and chatted about their current situation. This is important because the teacher makes students feel that they are cared for (Anderson, Liam, Garrison, and Archer 2001). Students were addressed by their names during the lessons (Aragon, 2003). He/she took the time to share his/her personal experiences and used humor and emotional symbols.

Thus, the students were encouraged to express their opinions without hesitation in a safe classroom atmosphere. In addition, the teacher kept his/her camera on and aimed to involve the students in the lessons more effectively. On the other hand, students' efforts to create their own meanings were supported by planning collaborative learning tasks following the learning objectives of the course (Anderson et al., 2001). 


\section{Results}

It was understood that teaching and cognitive presence were higher than social presence. It was also observed that the students perceived social presence at a moderate level. This finding showed that students perceived their teacher's activities and efforts adequate in the course design and conduct of instruction. Higher cognitive presence perceptions indicate that their online learning experiences are positive. On the other hand, it can be said that the students do not feel like they belong to the class and they cannot reflect themselves to the online environment as real individuals, that is, they perceive their social presence as lower than the other two elements. This finding was also supported by the opinions of the students. For example, M146 stated that "I feel like I am caught in platonic love. I see my friends, my class, my teachers, but I can't get together.” He obviously identified being deprived of communication and interaction with not being able to reach the person he fell in love with.

It was determined that the perception of teaching and cognitive presence of women was higher, but the perception of social presence did not change according to gender. This finding made us think that women perceive the teacher's contribution and guidance to learning in the ERT as more important. Women's cognitive presence scores were higher than men's. Thus, it was understood that women perceived their learning experiences in this process more positively than men. On the other hand, it is noteworthy that the perception of social presence does not differ significantly according to gender.

Receiving distance education through different LMS did not make a significant difference in students' perceptions of cognitive, social, and teaching presence. This finding may mean that the quality of online education is more affected by the design of the course process and teacher competencies rather than the LMS or the technology used.

In this study, in which the relationship between the three presences was examined, it was understood that teaching presence had a higher level and stronger relationship with cognitive presence than social presence. However, contrary to these results, there are some studies in the literature showing that social presence, not teaching, has a higher and more significant relationship with cognitive presence (Öztürk, Erdem and Deryakulu, 2017). According to these studies, which argue that the relationship between cognitive and social presence is more important, cognitive abilities targeted in higher education produce better results when integrated into cooperation because this situation is supported and maintained by the social presence (Gunawardena, 1995). The purpose of cognitive processes within a learning community is to promote the analysis, creation, and validation of meaning through reflection and discussion. However, it is natural that in the ERT, educational presence is perceived as more important than social presence (Erickson and Wattiaux, 2021) because there was no time left for it to be designed as a real distance education or blended learning model. Thus, teachers were more central in this process and focused on transferring the course content to the students. 
Another striking result of the study is that $47 \%$ of the students prefer face-toface teaching, $45.8 \%$ choose blended teaching, whereas only $7.2 \%$ opt for completely online teaching. This result showed that students prefer blended learning at a rate close to face-to-face education. In other words, the youth of the 21 st century have a positive attitude towards the integration of technology with educational processes and the effective use of technology in education.

\section{Discussion and Conclusions}

As a result, it is understood that the $\mathrm{CoI}$ is a theoretical model that can guide the development and evaluation of ERT. The most striking result of the study was that the perception of social presence was significantly lower than the cognitive and instructional presence perceptions. On the other hand, cognitive presence shows a positive and high-level relationship with teaching presence, as well as having a moderate and positive relationship with social presence, which is an important result for reaffirming the validity of the model. This relationship, which is especially emphasized in the literature, is also consistent with showing how important social presence is for achieving high-level cognitive learning goals and ensuring student satisfaction. It may be suggested to provide in-service training to educators about the design elements that will strengthen social presence in online learning communities.

\section{Ethics Committee Approval}

It was approved by the Biruni University Non-Interventional Clinical Research Ethics Committee with the evaluation dated 30.12.2020 and numbered 2020/46-39. 